\title{
A INTT,ELEGE ȘI A INOVA ARHITECTURA. O VIZITĂ LA LONDRA
}

Lect. dr. arh. Letiția Bărbuică

letitia.barbuica@headmade.ro

LONDON SOUTH BANK UNIVERSITY

The School of the Built Environment and Architecture LONDRA, MAREA BRITANIE

04/2019-05/2019 


\section{CONTEXT GENERAL}

În urma schimburilor Universitare din cadrul UAUIM², a experiențelor din cadrul diplomelor internaționale pe care universitatea le găzduiește în fiecare an, a obținerii validării RIBA ${ }^{3}$, s-au creat punți de comunicare solide între Universitatea de Arhitectura „Ion Mincu" din București și alte universități de aceeași specialitate din Europa, America, Asia. Astfel, s-a deschis posibilitatea unor vizite de lucru la alte școli de arhitectură pentru a observa și compara modul lor de lucru, de predare și învățare cu scopul de a păstra Universitatea de Arhitectura „Ion Mincu” aliniată practicilor internaționale de formare a viitorilor arhitecți.

London South Bank University este una dintre aceste universități partenere care și-a arătat disponibilitatea de a găzdui acest demers prin amabilitatea doamnei profesoare arhitect Lilly Kudic, directorul departamentului de arhitectură din cadrul LSBU ${ }^{4}$ care ne-a oferit întreaga deschidere, susținere și cooperare.

LSBU este o universitate internațională de mari dimensiuni ${ }^{5}$, localizată pe malul sudic al Tamisei, zona de o efervescentă dezvoltare urbană și arhitecturală și, din acest punct de vedere, un loc privilegiat pentru o școală de arhitectură: nu departe de TATE New Modern, un avanpost de reabilitare urbană a zonei și un proiect de arhitectură de excepție: proiect de reabilitare, extindere și refuncționalizare realizat de Herzog \& de Meuron. Clădirea în care funcționează departamentul de arhitectură oferă perspective aeriene asupra șantierelor în derulare din zonă precum și asupra unor clădiri emblematice cum ar fi The Shard - clădire de birouri realizată de Renzo Piano. (Fig. 1)

Departamentul de arhitectură din cadrul universității este organizat, ca toate programele recunoscute RIBA, în două etape de studii despărțite de un an de practică, respectiv RIBA part 1 - primii trei ani de studii, RIBA part 2 - echivalentul etapei de master din învățământul românesc. Sistemul de master integrat al UAUIM a fost recunoscut de

10 parte dintre ideile acestui articol au fost prezentate în colocviul Young Educators Scholarship, Masă rotundă, organizat în cadrul UAUIM în data de 1.10.2019.

2 Acronim pentru Universitatea de Arhitectură „Ion Mincu", București

3 Acronim pentru Royal Institute of British Architects, organizație care validează studiul arhitecturii la nivel universitar în Marea Britanie și în lume, acolo unde sunt îndeplinite standardele specificate în https://www.architecture.com/knowledge-and-resources/resources-landing-page/validationprocedures-and-criteria

4 Acronim pentru London South Bank University

5 Un număr de 18000 de studenți din 130 de țări și 7 facultăți distincte în cadrul Universității conform informațiilor de pe site-ul https://www.whatuni.com/university-profile/london-southbank-university/3821/ 
RIBA în februarie 2018, ca echivalent al sistemului englez de pregătire, studiu predare și practică. Această validare este valabilă pentru o perioada de 5 ani și trebuie reînnoită de orice universitate acreditată.

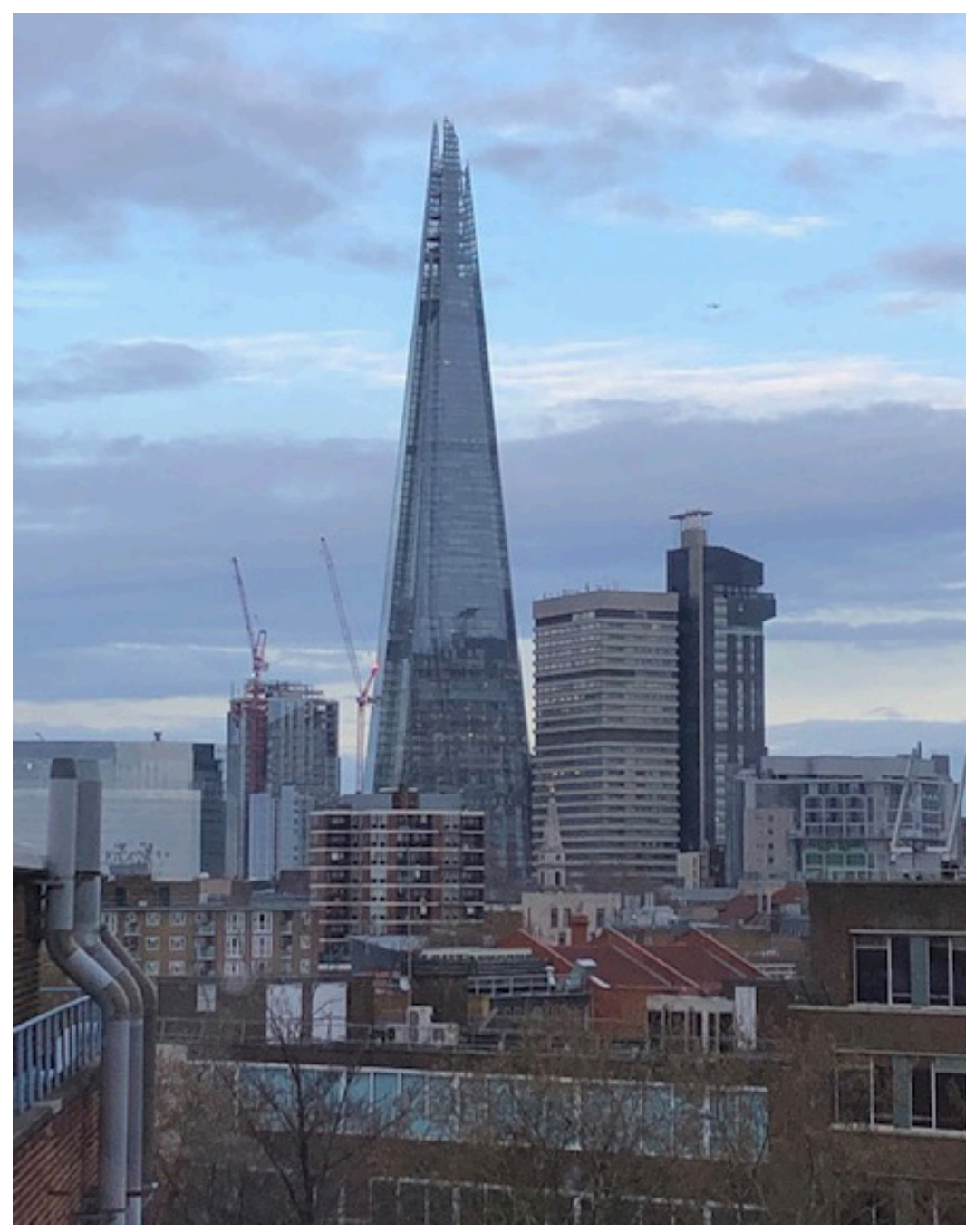

Fig. 1 Vedere The Shard din atelierele de proiectare ale departamentului de arhitectură LSBU. Sursa: Arhiva personală 


\section{DEMERS ȘI METODOLOGIE}

Pentru a înțelege parcursul pedagogic de la LSBU am stabilit două perioade de vizitare, în cadrul semestrului 2 al anului universitar 2019.

Prima perioadă a surprins un moment de desfășurare a proiectelor de arhitectură într-o etapă de mijloc de dezvoltare a proiectului de atelier. A doua perioadă a coincis cu susținerea finală a proiectelor. Într-un scenariu ideal o vizită la fundamentarea proiectelor și la expoziția finală ar fi fost, de asemenea, utilă. Studenții care au prezentat etapa curentă a proiectului au prezentat însă unele aspecte legate de începutul procesului de proiectare, lucru care a făcut posibilă urmărirea abordării pe întregul parcurs de proiectare.

Deși vizita a fost inițial concentrată pe urmărirea pedagogiei de la atelierul de proiectare, am reușit să surprind și să înțeleg elemente legate de cursul tehnic care este legat de proiectul de arhitectură dar și de teoria arhitecturii.

În etapa 1 a vizitei am asistat la toate atelierele: de la anul 1 la anul 5. Cel mai adesea am fost invitată să dialoghez cu studenții de pe poziția de invitat. Practic, am parcurs toate temele de studiu din cadrul atelierelor aferente semestrului 2 din cadrul facultății, participând la 3-4 prezentări de la fiecare grupă, în zile succesive. Numărul de ateliere pentru 2019 era de 9 conform tabelului de mai jos:

\begin{tabular}{|l|l|l|l|}
\hline an & $\begin{array}{l}\text { Număr de } \\
\text { ateliere }\end{array}$ & Număr studenți & Observații \\
\hline I & 1 & 40 & \\
\hline II & 2 & 20 & $\begin{array}{l}\text { 4 ateliere verticale cu câte } 10 \text { studenți din } \\
\text { fiecare an }\end{array}$ \\
\hline III & 2 & 20 & $\begin{array}{l}\text { 4 ateliere verticale cu câte } 10 \text { studenți din } \\
\text { fiecare an }\end{array}$ \\
\hline IV & 2 & 20 & \\
\hline V & 2 & 20 &
\end{tabular}

Tabel 1. Distribuție studenți pe ateliere

În etapa a 2-a a vizitei am asistat la juriul final, la toate atelierele, de la anul 1 la anul 5, în zile succesive. A fost interesant de urmărit cele câteva proiecte pe care din întâmplare le-am văzut și în etapa 1. (Tabelul 3 și Fig. 4)

în cadrul programului de master am aprofundat două elemente importante ale triadei de studiu care mă preocupă la nivel pedagogic: legătura proiectului de arhitectură 
cu științele tehnice și teoria arhitecturii. Astfel am parcurs programa legată de teoria arhitecturii și pregătirea disertației, împreună cu titularul acestui curs arhitecta Maria Theodoru. Am fost invitată, de asemenea, la cursul final de la științe tehnice, comun anilor 4 și 5.

Etapa 1 a vizitei s-a desfășurat în săptămâna 10 de studiu iar a doua în săptămâna 16. (tabelul 2)

Am adunat o serie de date pe care le voi prezenta în cele ce urmează și voi sintetiza niște observații. Concluziile se vor baza pe o comparație dintre UAUIM și LSBU legat de pedagogia de atelier precum și a procesului de desfășurare a proiectului.

Metodologia acestei cercetări are la bază adunarea de date la fața locului, analizarea și sortarea lor pentru a avea un punct de vedere informat. Concluziile prezintă niște posibile direcții de acțiune la nivelul UAUIM, validează niște strategii deja implementate și sugerează optimizări.

\section{PREZENTARE ȘI ANALIZĂ PENTRU ATELIERELE DE PROIECTARE AN 1-5}

Departamentul de arhitectură are un total de 120 de studenți dintre care 40 în anul 1 Foundation. Acest an este un modul accelerat de învățare și înțelegere a proiectului de arhitectură. Am asistat la dezvoltarea unui proiect de atelier pe un teren dificil pe malul Tamisei, ultimul proiect dintr-o serie de trei proiecte care sunt dezvoltate de studenții anului întâi. Acest an este considerat un an de pregătire (foundation) pentru viitorii studenți, dintre care doar o parte vor putea să continue studiile de arhitectură în cadrul universității. Este o pepinieră.

Anul 2 și 3 corespund anilor omologi din UAUIM și dezvoltă programa la nivel de licență. Pentru o mai mare diversitate a temelor de studiu atelierele sunt organizate vertical: câte 10 studenți din anul II și alți 10 studenți din anul III urmând un atelier condus de doi profesori titulari. Similar pentru anii IV și V. Fiecare atelier dezvolta deci două categorii de proiecte și de teme care se încadrează într-o tematică generală de an, similar sistemului de teme cadru din UAUIM ${ }^{6}$.

Între licență și master există un an de practică în birourile de proiectare iar LSBU este flexibilă și creativă în corelarea acesteia cu anii de studiu acceptând recent o categorie de studenți care continuă să lucreze în birouri de proiectare și să își continue studiile.

6 Spre exemplu https://www.uauim.ro/departamente/sp/teme4/ 
Anul 4 și 5 corespund anilor omologi de studiu din UAUIM cu o singură excepție: ultimul proiect de anul 5 este proiectul de finalizare de studiu, echivalentul proiectului de diplomă care se desfășoară la UAUIM în anul 6. Găsim aceeași organizare pe verticală a atelierelor pentru o mai mare diversitate de temă.

Organizarea studiului este similară cu sistemul existent și în UAUIM:

- 2 zile de atelier/ săptămână/ pentru fiecare an

- 2 zile de cursuri

- 1 zi de studiu individual pentru studenți/ 1 zi de administrație și organizare pentru profesori

În săptămâna 13 -17 mai 2019 am participat la susținerea finală a proiectelor. Aceasta este similară cu cea din UAUIM, dar este fără invitați externi, pentru că în sistemul lor există un evaluator extern al facultății care va discuta la final de an universitar cu fiecare student în parte în baza unui portofoliu. La fiecare proiect am avut acces la tema de proiectare care este organizată similar cu cele de la UAUIM dar are un grad mai mare de explorare. Fiecare proiect se desfășoară pe parcursul întregului semestru și acest lucru dă posibilitatea studenților să aprofundeze temele principale de studiu, contextul, să dezvolte teme program pe bază de interviuri sau informații locale introducându-i astfel în lumea cercetării și în studiul necesar fiecărui proiect.

Nu am participat la notarea efectivă a proiectului, însă prezentările, discuțiile, probleme ridicate în cadrul evaluării sunt similare cu o prezentare finală de la orice atelier din UAUIM. Ce mi s-a părut interesant este că după o notare individuală a atelierelor se trece la o notare comparativă pentru a avea un echilibru a notelor date la diferite ateliere. Aceasta se numește moderation week $k^{7}$ ș abia după această etapă de evaluare notarea proiectelor se consideră încheiată.

Lucrul studenților la proiect nu se încheie aici însă. Ei mai au 2 săptămâni la dispoziție pentru a-și perfecționa proiectul în baza celor discutate cu juriul și notei primite. Aceasta perioadă este în principal o perioadă de studiu individual. Acest lucru nu se va reflecta în nota finală care a fost deja obținută, dar proiectul îmbunătățit va putea fi parte din portofoliul final prezentat în fața evaluatorului extern.

Mi se pare valoros acest procedeu, pentru că nu este o mărire de notă în sine, ci o perfecționare pe care și-o asumă studentul, nu este obligatorie, nu este premiată cu o notă. Acesta este în contrast cu abordarea studenților de la UAUIM care sunt concentrați primordial pe notă, din observațiile mele.

Pe de altă parte, scopul construirii unui portofoliu valoros la finalul universității este

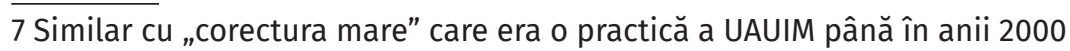


unul foarte important și studenții îl urmăresc încă din anul I. Astfel, acest proiect optimizat este parte din portofoliul care este prezentat examinatorului extern, în fapt unei comisii externe formată dintr-un practician de arhitectură și un arhitect din mediul academic. Studentul are la dispoziție 15-20 minute pentru un interviu iar procesul pentru întreaga universitate durează o săptămână. Examinatorii externi au decizia finală asupra celor care nu trec anul. O expoziție este organizată după parcurgerea acestei etape. Anul acesta, din cauza pandemiei Covid 19, expoziția s-a mutat online, prilej de expunere globală a rezultatelor celor mai buni studenți, pe platforma dezeen.com ${ }^{8}$.

8 https://www.dezeen.com/2020/06/29/london-south-bank-university-architecture-vdf-schoolshows/

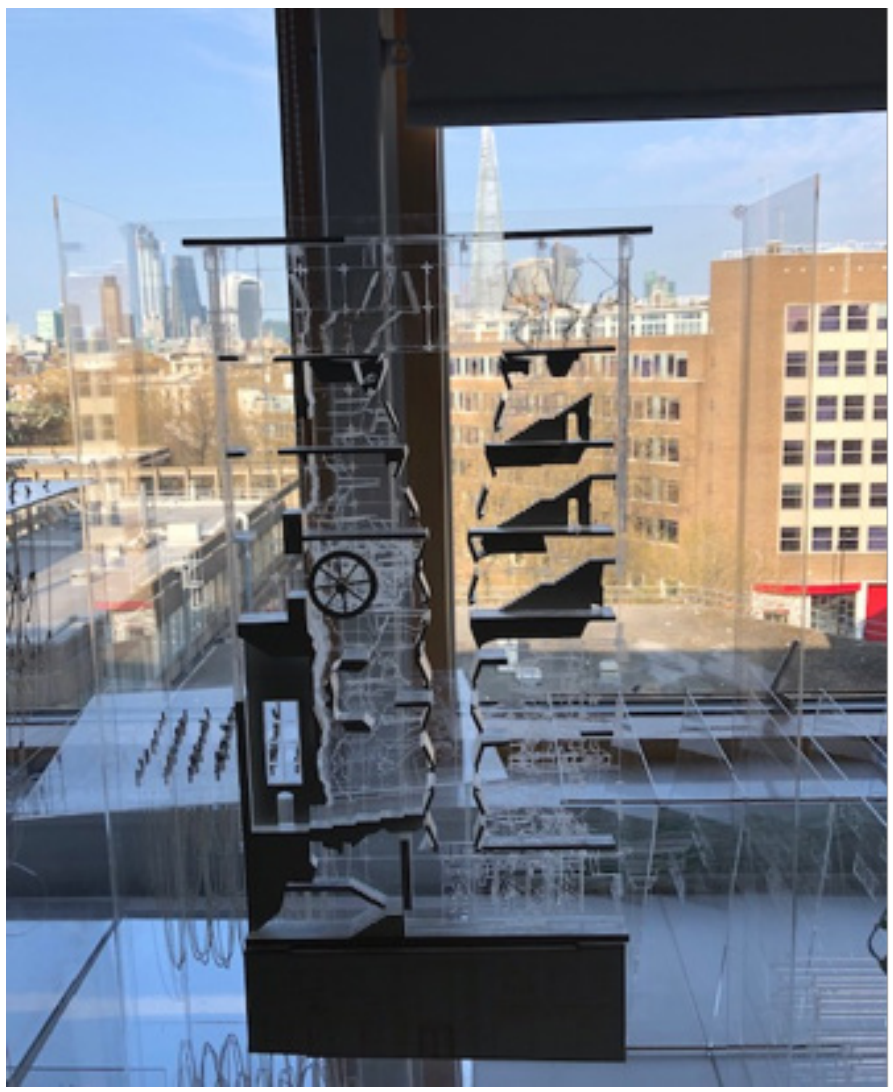

Fig. 2 Machetă de concept pentru o fabrică a viitorului, proiect an IV. Arhiva personală de imagini

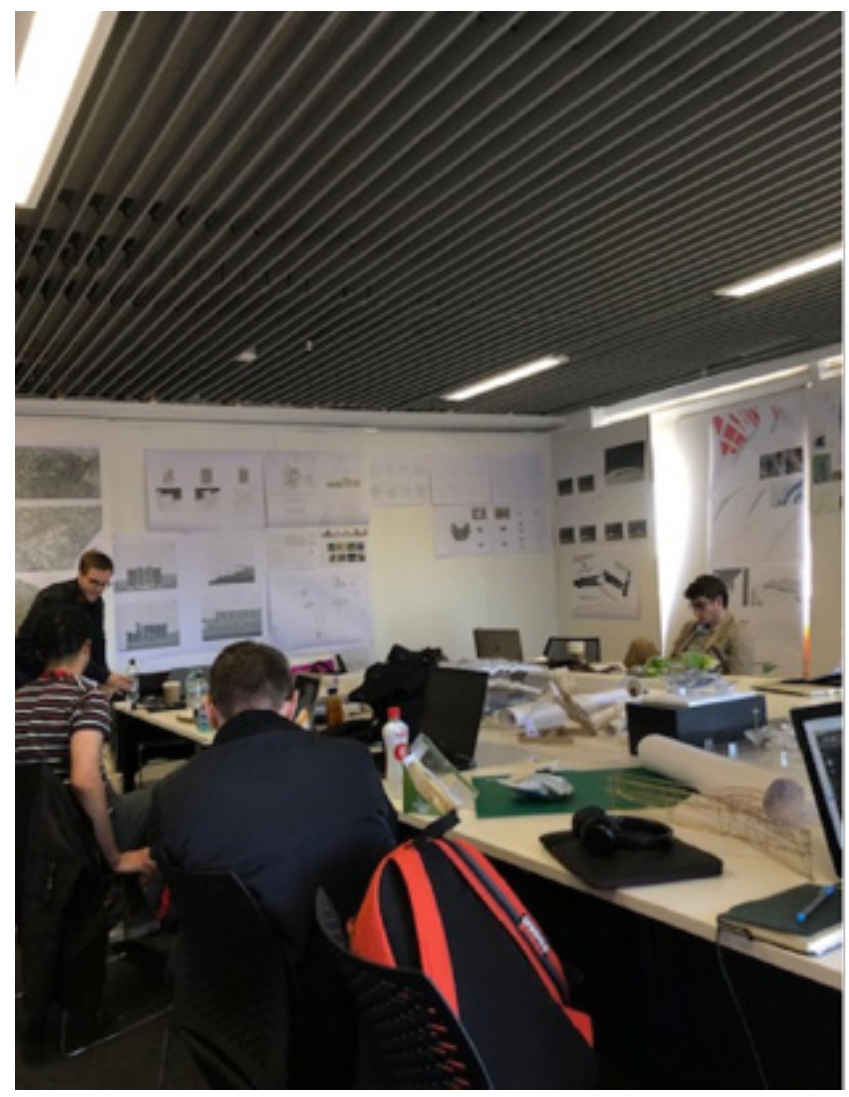

Fig. 3 Atmosferă de lucru din atelierul de proiectare, similară cu cea din UAUIM. Arhiva personală de imagini 
Atmosfera atelierului pe parcursul dezvoltării proiectului și la jurizare este similară discuțiilor la panou și juriilor din UAUIM. Am constatat însă o aplecare mai mare spre machetă în toate formele ei: de detaliu, de concept, aceasta fiind însă și o amprentă a unor ateliere individuale. (Fig. 2 și Fig.3)

Temele cadru de proiectare la care lucrau studenții pe parcursul vizitei mele (semestru 2, an universitar 2018-2019) au fost următoarele:

an 1 - Pe malul apei: stația Embankment Tamisa (foarte aproape de universitate)

an 2 - Clădiri rezidențiale lângă apă/ecosisteme protejate

an 3 - Studiul structurilor pe machete: Teatru în zonă istorică

Extindere pe structura existentă a unei stații de metrou (tema program dezvoltată de studenți)

an 4 - Reabilitarea zonelor destructurate/ abandonate:

Nou și vechi în Shoreditch (tema program dezvoltată de studenți)

Lucrul cu ruine/ situri istorice (tema program dezvoltată de studenți)

an 5 - Proiectând viitorul:

O fabrică pentru viitor

Un spital pentru viitor

Cu o singură excepție, cea a siturilor istorice și a temei legate de ruine, toate terenurile de studiu se aflau în Londra.

Proiectul anului 5, împreună cu dizertația dezvoltată ca parte a cursului de Teorie a arhitecturii constituie baza absolvirii Masterului de Arhitectură, RIBA part 2.

Ca observație, studenții își pot schimba universitatea de studiu după primii trei ani de studiu, în funcție de interesele lor - diverse universități fiind recunoscute pentru anumite abordări care le caracterizează.

Concluzionez că desfășurarea atelierelor și gradarea temelor de proiect este similară cu UAUIM. Totuși sunt niște puncte tari ale sistemului de la LSBU pe care le văd, astfel:

1. un singur proiect pe semestru care dă ocazia unei înțelegeri și dezvoltări în profunzime a programului și temei de studiu. Cred că acest proiect ar putea fi integrat treptat la anii 4 și 5. Actualmente doar proiectul de an 5, semestrul 2 are aceasta desfășurare. (Tabel 2)

2. timpul de lucru de după juriu mi se pare o manieră interesantă de a motiva studenții să se autodepășească, să iși perfecționeze proiectul și să minimizeze abandonul școlar. Acest lucru poate fi implementat doar împreună cu punctul 3, sau într-un sistem benevol de mărire de notă pe care studentul să și-l asume individual. De exemplu dacă un proiect de 8.30 cere mărire în urma juriului final nota nu este trecută în catalog și studentul revine peste 2 săptămâni în comisie. Dacă dezvoltarea proiectului nu asigură un rezultat 
mai bun, nota inițială se consemnează. Această perioadă de lucru ar trebui să fie una de studiu individual, exact cum este cea de la LSBU.

3. prezența examinatorului extern este și o cerință de la RIBA pentru implementare în vederea unei acreditări viitoare. UAUIM are acest sistem implementat deja în cadrul diplomelor internaționale. Cred însă că extinderea acestui sistem la toate etapele de studiu este dificil de implementat datorită numărului mare de studenți pe care îi are facultatea de arhitectură din București. Văd o eventuală aplicare locală doar pentru notele din grila cea mai de jos (sub 5.50) pentru a confirma faptul că studentul poate sau nu poate trece la o tema de studiu superioară ca extindere și complexitate și trebuie să refacă exercițiul anului respectiv. Punctul 2 s-ar putea aplica și în cazul lor, având o șansă în plus să nu piardă anul, luând însă în calcul o plafonare a notelor de trecere astfel obținute - prin mărire - la nota 6.

\begin{tabular}{|l|l|l|l|l|l|}
\hline Săptămâna 01 & 26.01 .2019 & Prezentarea temei & Săptămâna 09 & 25.03 .2019 & Atelier/ îndrumare \\
\hline Săptămâna 02 & 04.02 .2019 & Atelier/ îndrumare & Săptămâna 10 & 01.04 .2019 & Atelier/ îndrumare \\
\hline Săptămâna 03 & 11.02 .2019 & Atelier/ îndrumare & Săptămâna 11 & 08.04 .2019 & Vacanța de Paște \\
\hline Săptămâna 04 & 18.02 .2019 & Atelier/ îndrumare & Săptămâna 12 & 15.04 .2019 & Vacanța de Paște \\
\hline Săptămâna 05 & 25.02 .2019 & Prezentare la panou & Săptămâna 13 & 22.04 .2019 & Vacanța de Paște \\
\hline Săptămâna 06 & 04.03 .2019 & Atelier/ îndrumare & Săptămâna 14 & 29.04 .2019 & Prezentare la panou \\
\hline Săptămâna 07 & 11.03 .2019 & Atelier/ îndrumare & Săptămâna 15 & 06.05 .2019 & Atelier/ îndrumare \\
\hline Săptămâna 08 & 18.03 .2019 & Prezentare la panou & Săptămâna 16 & 13.05 .2019 & Susținere finală proiecte \\
\hline
\end{tabular}

Tabel 2. Etapele de desfășurare ale proiectului preluat din tema de proiect Design 503- studio 23; termenii au fost echivalați cu etapele care se parcurg la UAUIM (trad. ns).

\begin{tabular}{|l|l|}
\hline $\begin{array}{l}\text { BA [Hons] Architecture LSBU Studio 03 } \\
\text { Steve Bowkett \& Margarita Germanos }\end{array}$ & $\begin{array}{l}\text { March: Master of Architecture Studio } 21 \\
\text { Kira Ariskina \& Luke Saunders }\end{array}$ \\
\hline $\begin{array}{l}\text { March: Master of Architecture Studio 22 } \\
\text { Hasan Nourbakhsh \& Saam Kaviani }\end{array}$ & $\begin{array}{l}\text { BA [Hons] Architecture LSBU Studio 03 } \\
\text { Steve Bowkett \& Margarita Germanos }\end{array}$ \\
\hline $\begin{array}{l}\text { BA [Hons] Architecture LSBU Studio 02 } \\
\text { Spyridon Kaprinis \& Natascha Madeiski }\end{array}$ & $\begin{array}{l}\text { March: Master of Architecture Studio } 23 \\
\text { Lilly Kudic \& Luke Murray }\end{array}$ \\
\hline $\begin{array}{l}\text { BA [Hons] Architecture LSBU Studio 03 } \\
\text { Daniel Tang \& Todor Demirov }\end{array}$ & $\begin{array}{l}\text { March: Master of Architecture Studio } 20 \\
\text { Angelica Vaenzi \& Antonios Lalos }\end{array}$ \\
\hline
\end{tabular}

Tabel 3. Atelierele de proiectare vizitate, în ordinea desfășurării vizitei 


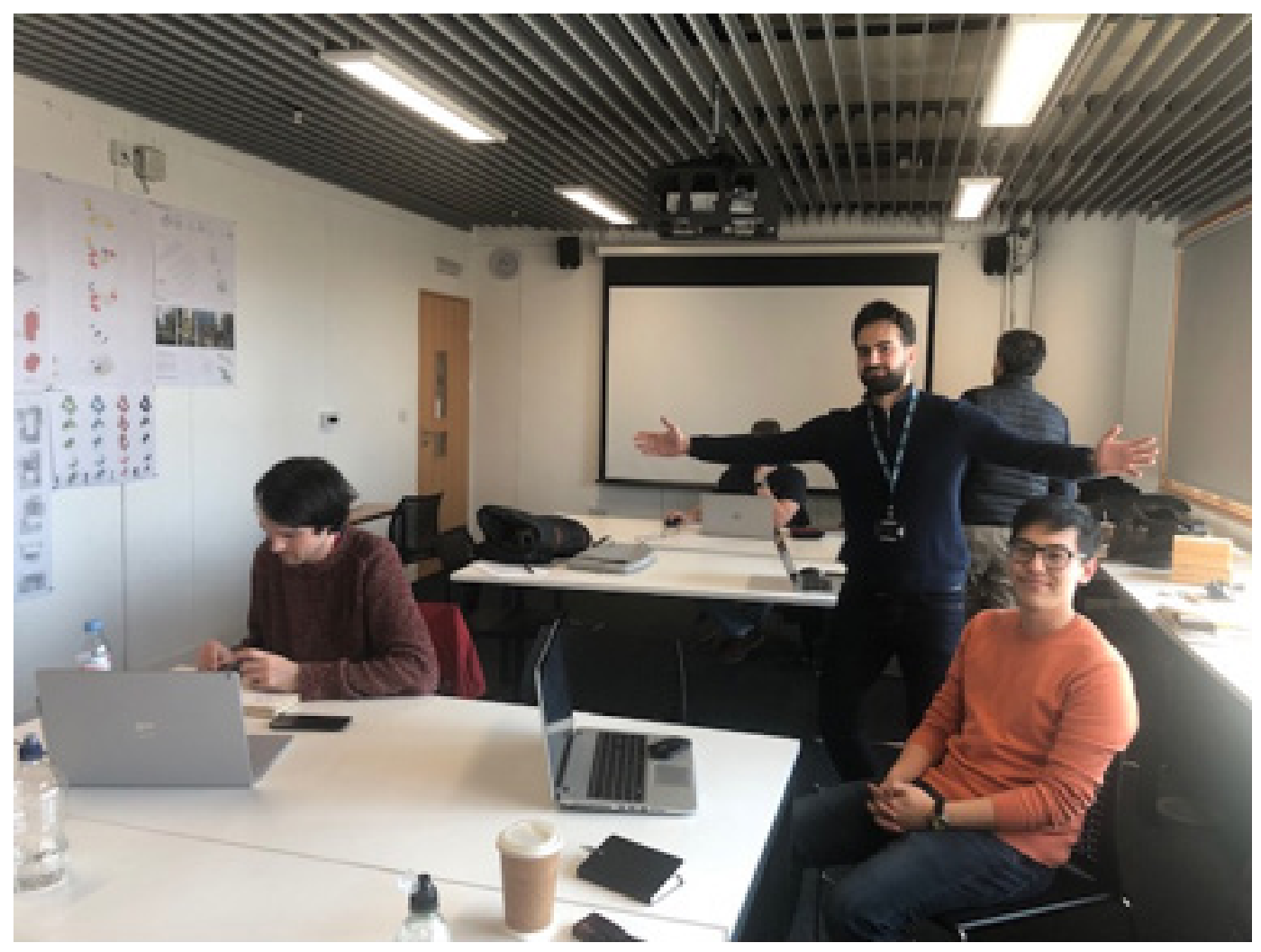

Fig. 4. Vizita la atelierul M Arch Studio 22. Atât profesorii cât și studenții au fost foarte deschiși iar discutiile comune pe proiectele prezentate au fost interesante, au deschis posibile directii de evolutie a proiectului, au identificat elemente de studiu pentru clarificări. Studenții s-au arătat receptivi, optimiști deschiși să caute soluții originale. 


\section{PREZENTARE ȘI ANALIZĂ PENTRU TEORIA ARHITECTURII "MODALITĂȚI DE GÂNDIRE"}

La momentul vizitei, cursul de Teoria Arhitecturii se finalizase. Prin amabilitatea arh. Lilly Kudic și arh. Maria Theodoru, titulara acestui curs, am obținut informațiile legate de desfășurare și conținut.

Acest curs se desfășoară pe parcursul a 10 săptămâni. Studenții au astfel o programă mai puțin încărcată la finalizarea proiectului de arhitectură respectiv săptămânile 11-16. (Tabelul 2). Pentru a avea o idee a subiectelor parcurse, am notat trei titluri de curs:

- curs 6 Architecture's Ghost: The 90's Deleuzean Toolkit for Architects ${ }^{9}$

- curs 9 Thinking Practice: Non- Philosophy for Architects ${ }^{10}$

- curs 10 Design What? ${ }^{11}$

Pentru fiecare curs se analizează un text și un proiect. Întrebările fundamentale urmărite sunt:

- CARE SUNT PROBLEMELE PE CARE ARHiteCtul A VRUt SĂ LE REZOlVE?

- A VENIT CU CEVA INOVATIV?

La aceste cursuri se adaugă 3 seminare de scriere academică.

În anul IV tema este un eseu de 2000 de cuvinte, un exercițiu de gândire. Studenții primesc evaluări pentru: cercetare, prezentare, calitatea scrisului, citare și organizarea

9 „Himera arhitecturii: instrumente de lucru ale lui Deleuze din anii 90" (trad. ns)

10 Concept filozofic dezvoltat de François Laurelle

11 „Ce proiectăm acum?” (trad. ns) 
referințelor. Acest eseu valorează 5 credite din 20 aferente semestrului.

Deja din semestrul 2 a anului IV se începe pregătirea disertației ce va fi prezentată la finalul anului $V$ ca parte a absolvirii. Astfel, studenții au la dispoziție trei semestre de lucru îndrumat pentru disertație și o vacanță de vară pentru documentare. Comparând timpul de lucru disponibil pentru disertație, UAUIM nu poate participa de la egal la egal, în acest moment, la Dissertation Medal, competiție organizată pentru toate universitățile recunoscute RIBA.

În semestrul 2 al anului IV studenții își aleg tema de disertație care nu are nici o legătură cu tema de proiectare, diferit de abordarea din UAUIM. Abordarea UAUIM li s-a părut interesantă - legătură directă între tema de diplomă și disertație - dar în cazul LSBU greu de realizat datorită etapizării acestui studiu.

Tot în semestrul 2 se predau 5 cursuri de metodologie iar la sfârșitul semestrului studenții trebuie să predea:

\section{DISERTATION RESEARCH PROPOSAL ${ }^{12}$ + DISERTATION PRIMARY RESEARCH FORM ${ }^{13}$}

Pentru această etapă nu se dau credite ci doar calificativ admis/respins. Dacă un student este respins el nu se poate înscrie la disertație.

Vacanța de vară dintre anii 4 și 5 este dedicată parcurgerii textelor identificate ca bază de studiu pentru cercetare/ disertație.

Anul V este dedicat integral pregătirii disertației pe baza punctelor de plecare stabilite la finalul anului IV, și a bibliografiei parcurse peste vară. în anul V au loc întâlniri săptămânale de 20 minute cu fiecare student pentru a monitoriza progresul lucrării, a depăși blocajele, a clarifica noi posibile direcții de studiu.

Studenții primesc și feedback scris la anumite etape mai dezvoltate ale disertației.

\section{PREZENTARE ȘI ANALIZĂ CURS TEHNIC}

La momentul vizitei, cursul tehnic se finalizase, el desfășurându-se în primele 10 săptămâni din semestru, întocmai ca Teoria Arhitecturii. Am asistat la un curs care s-a recuperat în săptămâna 16 (vezi tabel 2). Cursul a fost comun studenților din anul 4 și 5 și a tratat noțiuni legate de structuri subterane, fundații, pereți de susținere. Cursul de două ore a prezentat un istoric al clădirilor subterane, a analizat succint exemple de construcții contemporane de diverse dimensiuni, a prezentat o secțiune la nivel de

12 P,ropunere de cercetare pentru disertație" (trad. ns)

13 „Schema de dezvoltare a cercetării" (trad. ns) 
proiect tehnic. Cursul a cuprins și câteva elemente de predimensionare necesare unui arhitect, dar nu a intrat în detalii de calcul, formule, teorii, diagrame sau informații inginerești.

Titularul cursului participă la discuțiile de la fiecare atelier și identifică problemele tehnice, structurale, detaliile ce necesită studiu pentru a fi integrate în proiect. Astfel proiectul tehnic este parcurs în paralel cu proiectul de arhitectură fiind strâns legat de proiectul de arhitectură și de ritmul lui de evoluție. Proiectul tehnic nu are alt scop în sine decât ancorarea proiectului de arhitectură în toate elementele tehnice necesare înțelegerii lui și este particularizat pentru fiecare student în parte. La anul V spre exemplu există 2 livrabile legate de proiectul tehnic:

1. parte scrisă ${ }^{14}$ : o analiză structurală a unor clădiri - în legătura cu tema de studiu de la proiectul de arhitectură

2. parte desenată: detalii $1 / 20$ ale proiectului de arhitectură

Acestea se dezvoltă pe întreaga perioadă de desfășurare a proiectului de arhitectură (săptămânile 1-16) dar lucrările se finalizează, se predau și se notează în cele 3 săptămâni de studiu individual de dinainte de expoziția finală de proiecte. (Tabelul 4)

Această etapizare mi se pare benefică pentru proiectul de arhitectură. Proiectul tehnic vine să sprijine proiectul de arhitectură, îi dă suficient timp să se dezvolte și nu are agende rigide ci scopuri extrem de flexibile, de o diversitate egală cu diversitatea proiectelor de arhitectură. Cerințele cursului tehnic nu implică cunoștințe matematice, ci o înțelegere a sistemelor constructive și a proprietăților materialelor de construcții. Este vorba despre foarte mult efort și studiu individual, rezultatele proiectelor de orice natură având o componentă de $60 \%{ }^{15}$ studiu individual.

\begin{tabular}{|c|c|c|c|c|c|c|c|c|c|c|c|c|c|c|}
\hline & & & & & \multicolumn{10}{|c|}{ Sheet1 } \\
\hline w1 & w2 & w3 & w4 & w5 & w6 & w7 & w8 & w9 & w10 & w11 & w12 & w13 & w14 & w15 \\
\hline \multicolumn{12}{|c|}{ proiect de arhitectură } & $\begin{array}{l}\text { final } \\
\text { crit }\end{array}$ & & \\
\hline \multicolumn{10}{|c|}{ curs de tehnologie } & & & & & \\
\hline & & & & & & \multicolumn{6}{|c|}{ proiect tehnic } & & $\begin{array}{l}\text { tech } \\
\text { report }\end{array}$ & $\begin{array}{l}\text { moder } \\
\text { ation }\end{array}$ \\
\hline
\end{tabular}

Tabel 4. Etapizarea cursurilor și proiectului tehnic în funcție de proiectul de atelier

14 „Technical thesis” (trad. ns.)

15 Conform https://www.lsbu.ac.uk/study/course-finder/architecture-ba-hons 


\section{CONCLUZII}

A înțelege și a inova sunt elemente esențiale care, în înțelegerea mea, structurează demersul pedagogic atât a atelierului de arhitectură, a cursului tehnic cât și a teoriei de arhitectură.

Dacă cursul tehnic urmărește îndeaproape proiectul de arhitectură, teoria de arhitectură structurează un mod de gândire ce poate fi aplicat atât la nivelul proiectului cât și a lucrărilor scrise ${ }^{16}$ de pe parcurs.

Lucrul în ateliere verticale mi s-a părut interesant și benefic pentru studenți, cred însă că acesta nu este aplicabil la UAUIM dar poate fi aplicat la universitățile din țară unde numărul de studenți este mai mic. Avantajele ar fi:

- un număr mai variat de teme de studiu (practic dublarea lor)

- interacțiunea studenților pe verticală, benefică biunivoc

- posibilitatea unui student de a fi în atelierul oricărui profesor, toți profesorii predând concomitent la anii 2 și 3 și nu doar din 2 în 2 ani la anul 2 și din 2 în 2 ani la anul 3 sistemul existent în UAUIM

Multe lucruri le-am găsit similare în pedagogia de atelier, însă concentrarea pe inovare, concept, tehnologie/ ecologie mi s-au părut a fi mult mai programatic urmărite decât în facultatea noastră.

Elementele de organizare care ar putea fi preluate în cadrul UAUIM:

\section{Atelierul de arhitectură:}

- organizarea în 10 săptămâni intensive de curs care ar lăsa un timp de lucru dedicat, spre finalul proiectului, doar părții de proiectare.

- proiect unic pe semestru (an 4, an 5)

- timp de lucru după jurizarea finală pentru optimizarea proiectelor, cu sau fără mărire de notă

- organizarea unei expoziții fizice sau online FINAL SHOW. Pornind de la modelul LSBU, am organizat anul acesta (2020) expunerea virtuală a celor mai bune proiecte de diplomă. Acestea pot fi văzute la https://www.uauim.ro/evenimente/best-diploma-projectsuauim/.

- $60 \%$ studiu individual

16 Denumite generic „thesis”, ca de exemplu partea scrisă a proiectului tehnic care se numește „Technical Thesis” sau „Dissertation”. 


\section{Teoria arhitecturii/ disertație}

- lucrare similară cu dizertația, de mai mici dimensiuni, îndrumată, ca un prim antrenament pentru lucrarea de la finalul anului 6 (spre exemplu în anul IV)

- desfășurarea disertației pe 3 semestre, începând din semestrul 2 al anului V, cu timp de lectură peste vară.

- organizarea unor cursuri scurte și specifice legate de metodologie și redactare. La LSBU sunt 3 pentru fiecare, suficiente pentru a pune baza unui mod de abordare corect și riguros.

\section{Proiectul tehnic:}

- organizare etapizată cu doar 10 săptămâni de curs și timp dedicat proiectului tehnic

- predarea proiectului tehnic după predarea celui de arhitectură

- flexibilitatea obiectivelor care să urmărească îndeaproape fiecare proiect de arhitectură cu specificul său

- participarea coordonatorilor de la proiectul tehnic în cadrul atelierului pentru clarificarea aspectelor tehnice, eventual la prezentările de panou când proiectele sunt înaintate

- $60 \%$ studiu individual

Elementele de conținut și abordare care ar putea fi preluate în cadrul UAUIM:

- modul de fundamentare al proiectului (concept)

- o legătură aproape invizibilă cu proiectul tehnic: să nu știi unde începe primul și unde se termină altul. Exemplul proiectului tehnic din UAIM care impune studiul umbririi, poate fi obiectivul unor seminare, dar este artificial ca 300 de studenți din anul IV să aibă soluții de umbrire în proiectul de arhitectură, doar pentru a bifa o cerință legată de proiectul tehnic.

- teme de proiectare exploratorii

- interes pentru inovare (de orice fel: spațială, de abordare, de detaliu etc)

- interes pentru tehnologie/ noile tehnologii/ ecologie

- nota nu este un scop în sine, în schimb valoarea și calitatea portofoliului ${ }^{17}$ de proiecte studențești este. (ar trebui să fie)

17 Se vorbește prea puțin despre portofoliu, care în UK este foarte important pentru angajare și ca atare este un focus important pe parcursul anilor 1-3 pentru practica din anul 4, iar în anii terminali pentru postul de după terminarea studiilor. 
Vizita la London School of Built Environment, departamentul de arhitectură, mi-a arătat că UAUIM are locul ei bun între școlile europene de arhitectură și trebuie să se adapteze continuu, să se modernizeze, să preia noi obiective, să modifice altele existente. Ethosul atelierelor de arhitectură de la LSBU și de la UAUIM mi s-a părut similar, deși cultura studiului individual a studenților mi s-a părut mai dezvoltată la Londra. Întâlnirea cu pedagogi pasionați, cu studenți optimiști și harnici, a fost o reală bucurie și inspirație.

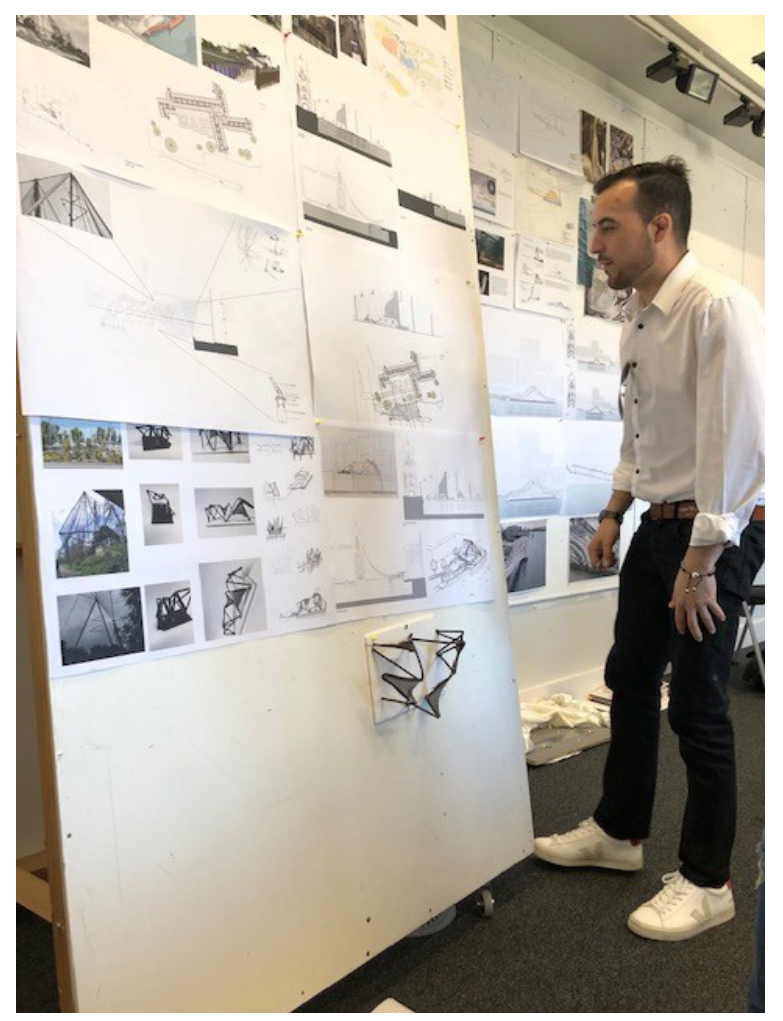

